\title{
Clinical-statistical study concerning the root caries prevalence and the correlation with etiological factors
}

\author{
Studiu clinico-statistic privind prevalenţa cariei radiculare şi corelaţia cu \\ factori etiologici
}

Nazem Dawod, Cornelia Bîcleşanu, Anamaria Florescu

Universitatea „Titu Maiorescu“, Bucureşti, România

\begin{abstract}
Root caries (RC) are considered a major oral health problem in the elderly, different studies showing its complexity and multifactorial nature. The aim of this study is to evaluate in a group of patients, the prevalence of $\mathrm{RC}$ and the correlation with etiological factors.

Material and method. This study was conducted on a group of 320 patients aged between 55 and 85 years old, which came for consultation and treatment during 2015-2017. Of these, 180 patients showed a number of 280 RC. RC diagnosis was performed according to the modified Dental Decay and Assessment Code (ICDAS II). Each patient received a consultation card and in addition, each one completed a questionnaire about risk factors that may cause RC.

Results. The present study analyzed the prevalence of root caries and the correlation between root caries index $(\mathrm{RCI})$ and several categories of etiological factors. Of the total group of 320 patients, $180(36 \%)$ patients had RC, $92(51 \%)$ were males and $88(49 \%)$ females. It was found that the number of RC at the maxillary is higher $(57 \%)$ compared to the mandible (43\%). Half of the RC are located on the facial aspect of the teeth, proximal areas are interested in relatively equal proportions ( $27 \%$ on mesial surfaces and $23 \%$ on distal surfaces). The incidence of root caries is related to risk factors like age $(p=0.037)$ and gingival recession $(p=0.013)$, dental hygiene $(p=0.039)$, alcohol consumption $(p=0.034)$, smoking $(p=0.050)$ and financial situation $(p=0.021)$.

Conclusions. Knowledge of risk factors and their correlation with the RCI may lead to the development of some preventive protocols and individual curative treatment in accordance with the risk group of each patient.
\end{abstract}

Keywords: root caries, risk factors, root caries index

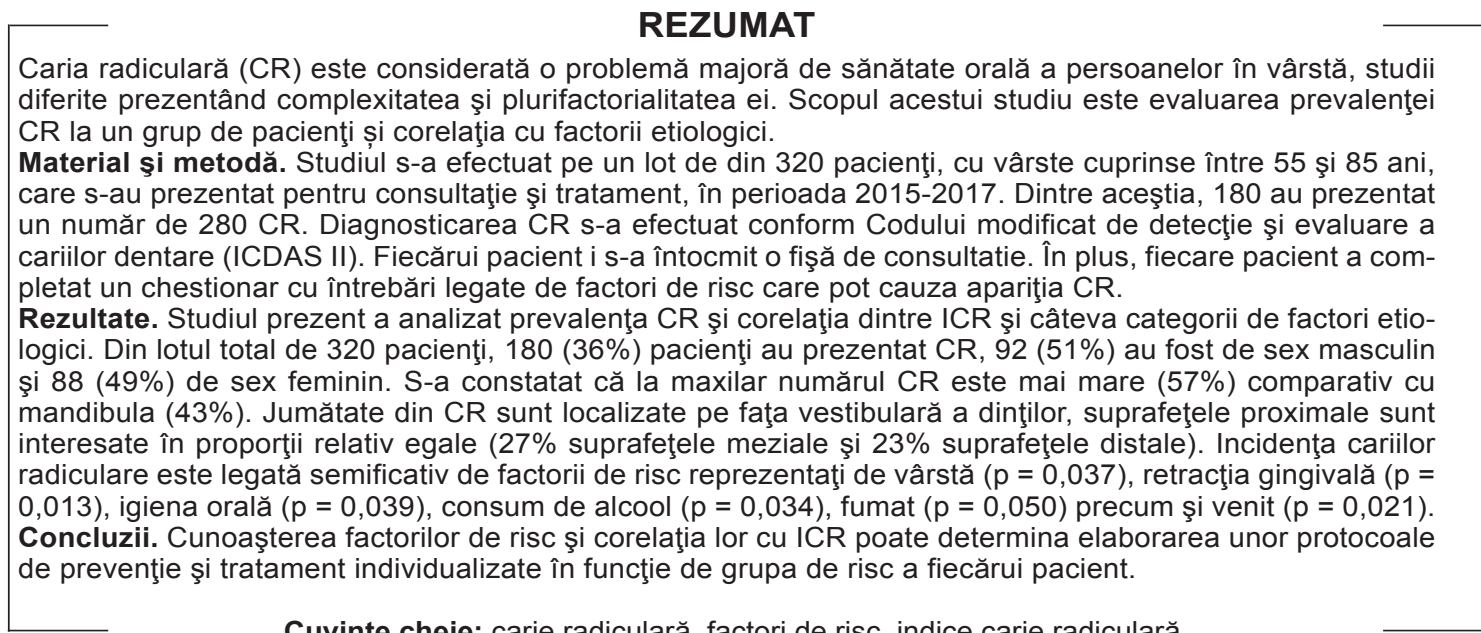




\section{INTRODUCERE}

În ultimii ani, caria radiculară (CR) este considerată o problemă majoră de sănătate orală a persoanelor în vârstă. OMS consemnează creşterea continuă a speranței de viaţă care s-a extins în ultimii ani, astfel încât aceasta a ajuns la 60 de ani şi chiar peste această vârstă. Astfel, în România, limita de viață este de 75 de ani la femei şi 68,5 ani la bărbați, potrivit unui raport al Comisiei Europene. Dacă acest proces este asociat şi cu îmbunătățirea sănătății dentare şi, întrucât prezența CR este asociată persoanelor vârstnice, incidența ei ar trebui să fie în creştere continuă.

Un studiu recent a identificat trei vârfuri ale activității cariilor, respectiv la 6, 25 şi 70 de ani. Vârsta de 70 de ani a fost legată de prezența CR produse de expunerea suprafețelor radiculare ca urmare a pierderii suportului parodontal (1).

Aceste suprafețe devin mai sensibile la acumularea de biofilm dentar, iar îndepărtarea lui este adesea dificilă pentru persoanele în vârstă din cauza dexterității manuale limitate (2).

Datele din literatura de specialitate sugerează că un număr tot mai mare de pacienți adulți se prezentă la cabinetele de medicină dentară cu CR.

Gupta şi colab. au raportat un procent de leziuni noi în curs de dezvoltare de la 36\% la 67\% (3).

Hellyer însă, citat de Gupta B., a raportat o prevalenţă de 88,4\% la pacientii de 55 de ani şi peste această vârstă. Imazato S. a raportat că 39\% dintre subiecți au avut una sau mai multe carii radiculare şi 53,3\% au avut cel puțin o leziune carioasă sau o restaurare. CR au fost observate cel mai frecvent la dinții canini, urmate de cele de primul premolar (4).

În Finlanda, în 2010, proporția celor cu vârstă de 65 de ani sau peste a fost de $17,5 \%$ şi este în creştere astfel că până în 2060 proporția corespunzătoare a fost estimată la 28,8\% (5).

De altfel, în Finlanda, un sondaj național privind sănătatea în 2011, a arătat că leziunea carioasă a fost frecventă în grupurile de vârstă de 75 de ani şi peste. Mai mult de jumătate dintre bărbați şi $21 \%$ dintre femeile din această grupă de vârstă aveau cel puțin un dinte cu leziuni carioase (6).

Pentru Kumara-Raja B. şi colab., CR reprezintă patologia frecventă a pacienților de vârsta a treia, dar şi motivul principal de pierdere a dinților. S-a raportat că aproximativ o treime din populaţia în vârstă prezintă acest tip de carie (7).
În ceea ce priveşte etiologia, studiile arată complexitatea şi plurifactorialitatea CR. Ritter A.V. şi colab. au identificat ca responsabili de producerea CR factorul socio-demografic, starea de sănătate sistemică, factori orali şi comportamentali (8).

Scopul acestui studiu este evaluarea prevalenţei CR la un lot de pacienţi şi corelaţia cu factorii etiologici.

\section{MATERIAL ŞI METODĂ}

Studiul s-a efectuat pe un lot de 320 pacienţi cu vârste cuprinse între 55 şi 85 ani, care s-au prezentat pentru consultaţie şi tratament, în perioada 2015-2017, într-un cabinet privat din Bucureşti. 180 pacienți din acest lot au prezentat un număr de 280 CR. Criteriile de eligibilitate în studiu au constat în prezența a minimum 6 dinţi naturali pe arcade, pacienți fără afecțiuni parodontale în curs de tratament şi cu care se poate colabora. Diagnosticul a fost stabilit prin consultaţie de către un singur examinator, prin examinare vizual-tactilă cu magnificaţie şi iluminare corespunzătoare.

Diagnosticarea CR s-a efectuat conform Codului modificat de detecție şi evaluare a cariilor dentare (ICDAS II), conform căruia CR se clasifică după două criterii, codul leziunii carioase şi codul activității carioase.

\section{Cod E}

Suprafața radiculară nu poate fi vizualizată (acoperită de tartru).

\section{Cod 0}

Suprafața radiculară nu prezintă modificare de culoare sau defecte ale suprafeței radiculare sau la joncțiunea cement-smalț si are un contur anatomic normal.

Suprafaţa radiculara poate să prezinte o pierdere definitivă a continuității suprafeței sau conturului anatomic, de obicei pe suprafața vestibulară, care nu este în concordanță cu criteriile de diagnostic al cariilor dentare şi este însoțită de obiceiuri dietetice specifice care se diagnostichează ca lezuni necarioase de tipul abraziune sau eroziune.

\section{Cod 1 (leziune incipientă)}

Există o zonă delimitată clar pe suprafața rădăcinii sau la joncțiunea cement-smalț care prezintă modificări de culoare (maro deschis/închis, negru), fără cavitație (pierderea conturului anatomic $<0,5$ $\mathrm{mm}$ ). 


\section{Cod 2 (leziune extensivă moderată)}

Există o zonă delimitată clar pe suprafața rădăcinii sau la joncțiunea cement-smalț care prezintă modificări de culoare (maro deschis/închis, negru) şi există cavitație (pierderea conturului anatomic 0,5 mm-2 mm (moderată), > 2 mm (extensivă) (9).

Schema criteriilor de diagnosticare a unei leziuni carioase ca fiind radiculară este prezentată în Fig. 1.

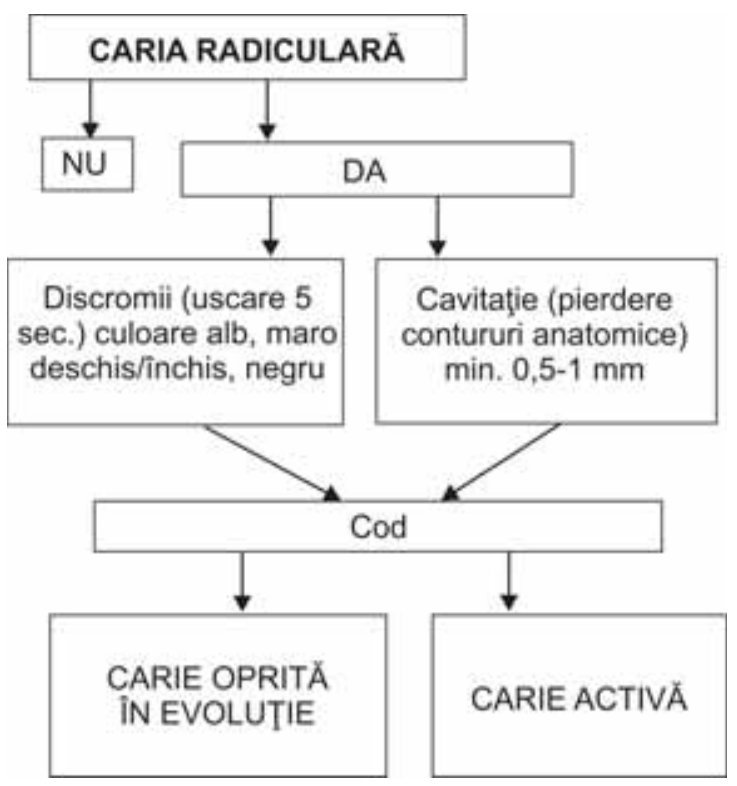

FIGURA 1. Diagnosticul cariei radiculare
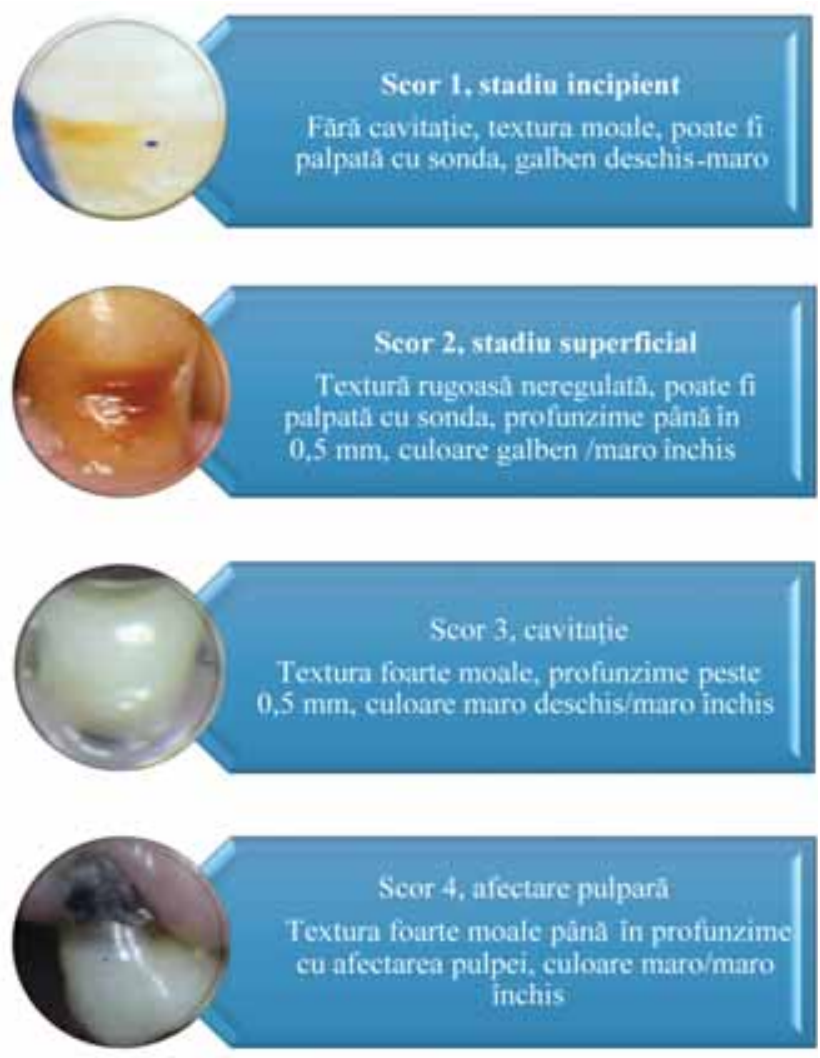

FIGURA 2. Scorurile CR (10)
Ținând cont de aceste criterii după ce leziunile au fost diagnosticate ca fiind CR, ele au fost clasificate, după profunzime, cu ajutorul scorurilor reprezentate în Fig. 2.

Fiecărui pacient i s-a întocmit o fişă de consultație în care s-a evidenţiat statusul dentar şi parodontal. În plus, fiecare pacient a completat un chestionar cu întrebări legate de o serie de factori de risc care pot cauza apariţia CR.

\section{REZULTATE}

Din lotul total de 320 de pacienți, 180 (36\%) pacienți au prezentat CR (Fig. 3).

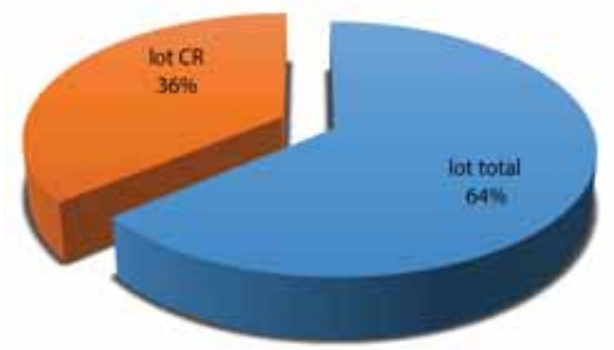

FIGURA 3. Repartiția lotului total

Din cei 180 de pacienți care au prezentat CR, 92 (51\%) au fost de sex masculin şi 88 (49\%) de sex feminin (Fig. 4). Lotul a fost împărțit în 3 categorii de vârstă: 55-65 ani, 66-75 ani, 76-85 ani (Fig. 5).

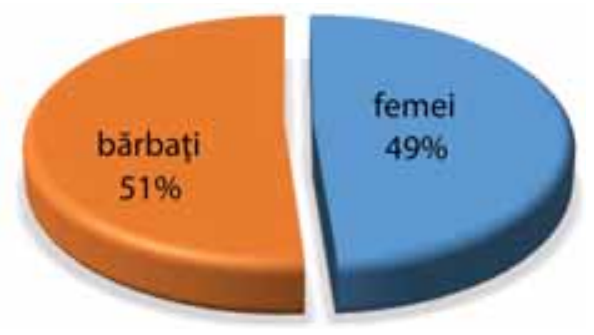

FIGURA 4. Repartiție lot pe sexe

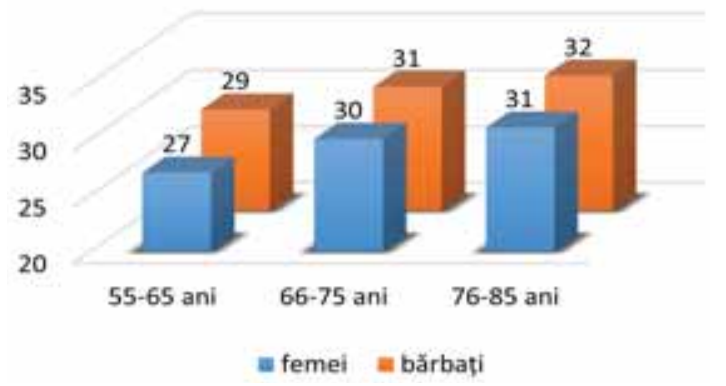

FIGURA 5. Repartiție lot pe sexe şi grupe de vârsta

Se constată că pacienții de sex masculin reprezintă puţin peste jumătate din lotul studiat (51\%); în ceea ce priveşte grupele de vârstă, se constată că 
prezența CR creşte proporțional cu vârsta, cu o uşoară preponderență la sexul masculin.

Starea de sănătate a pacienților evaluată conform clasificării Societății Americane a Anesteziştilor (ASA) (11) este prezentată în Fig. 6.

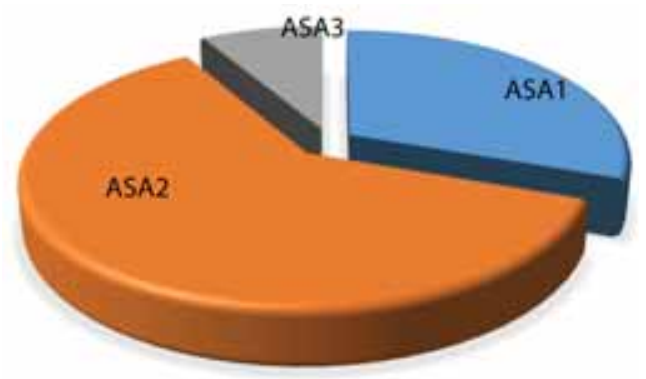

FIGURA 6. Distribuția stării de sănătate

Se constată că peste jumătate din pacienți au prezentat boli sistemice uşoare (ASA2) şi doar $8 \%$ au prezentat o stare de sănătate mai severă tradusă prin hipertensiune arterială şi diabet zaharat netratate, obezitate morbidă, insuficiență renală cronică sau angină (ASA3). Nu au existat pacienți din categoria ASA4.

În ceeace priveşte nivelul de educaţie, 97 (54\%) dintre pacienți prezentau studii medii, iar 83 (46\%) studii superioare (Fig. 7).

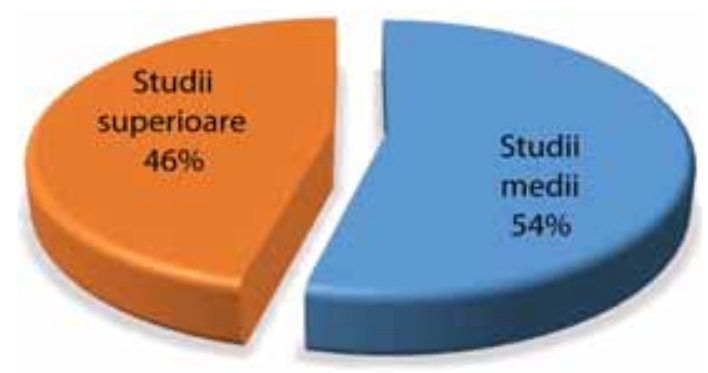

FIGURA 7. Repartiția lotului după nivel educațional

Din punctul de vedere al repartiției CR pe arcadele dentare, s-a constatat că la maxilar numărul lor este mai mare (57\%) comparativ cu mandibula (43\%) (Fig. 8).

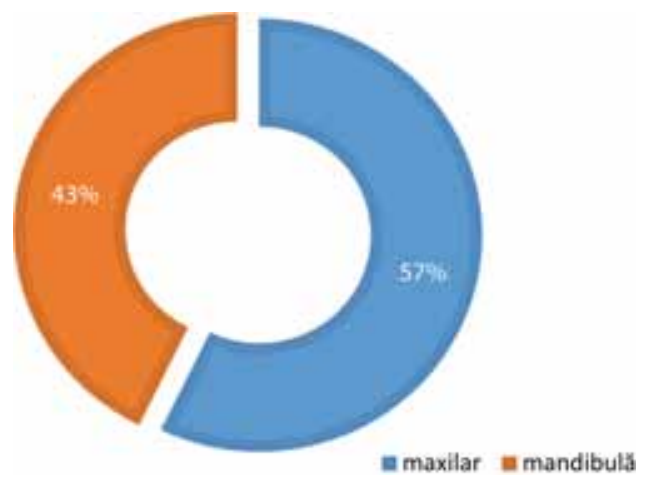

FIGURA 8. Repartiția cariei radiculare pe arcade
S-a verificat şi modul în care CR sunt însoțite de retracție gingivală (Fig. 9). Se constată că doar 1/3 dintre dinții cu CR nu sunt însoțiți de retracție gingivală.

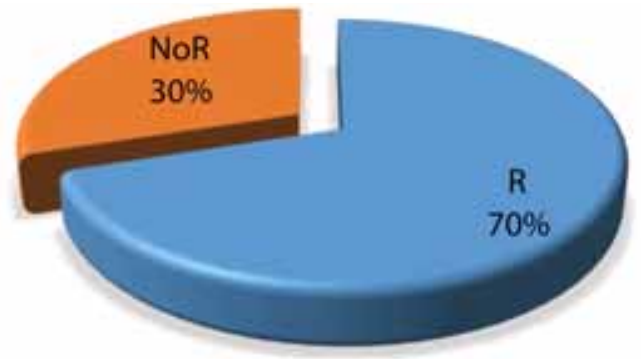

FIGURA 9. Prezența retracției gingivale

Repartiția pe categorii de dinți a retracției gingivale arată că în lotul studiat cei mai afectați sunt PM (67), urmați de M (38) (Fig. 10).

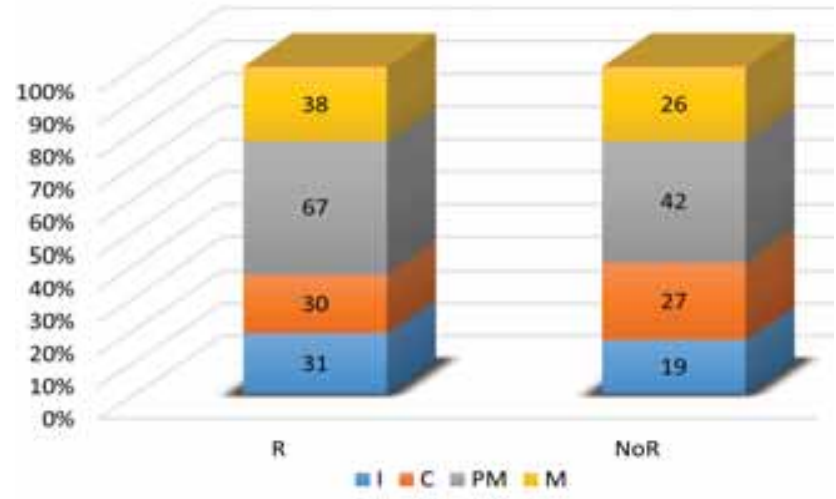

FIGURA 10. Repartiția retractiei gingivale pe categorii de dinți

Repartiția CR pe suprafețele dentare este prezentată în Fig. 11. Jumătate dintre CR sunt localizate pe fața vestibulară a dinților, suprafețele proximale sunt interesate în proporții relativ egale $(27 \%$ suprafețele meziale şi $23 \%$ suprafețele distale).
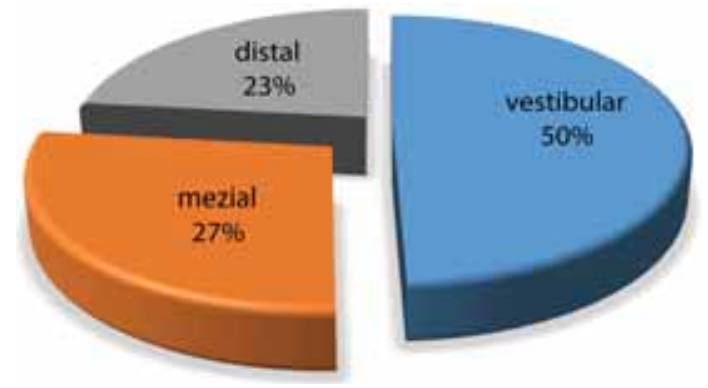

FIGURA 11. Repartiția CR pe suprafețele dentare

Am verificat ipoteza că leziunile radiculare sunt mai frecvente pe dinţii care prezintă carii şi pe alte suprafețe. S-a constatat că numărul CR asociate cu 
prezența cariilor pe alte suprafețe dentare este mai mare comparativ cu numărul de carii solitare, reprezentând aproximativ $3 / 4$ din lot (Fig. 12).

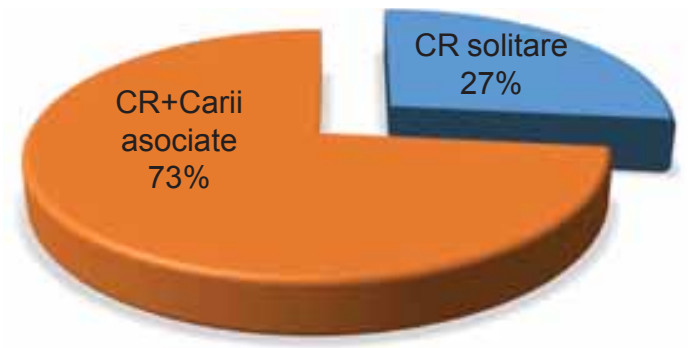

FIGURA 12. Repartiția cariei radiculare în funcție de alte suprafețe afectate

Repartiţia CR pe categorii de vârstă, dinți şi maxilare arată că în categoria 55-65 ani există cea mai mare incidență a CR la nivelul premolarilor (PM), cu un număr de 28 PM la maxilar şi 33 mandibular, la categoria de vârsta 66-75 ani, numărul de PM cu CR scade la 12 la maxilar şi 15 la mandibulă, pentru ca la categoria 76-85 ani să avem 15 PM la maxilar şi 18 la mandibulă care prezintă CR. Caninii sunt afectați de CR în număr mare, astfel că la categoria de vârstă 55-65ani există la maxilar 16 şi 12 la mandibulă, la categoria 66-75 ani, 8 la maxilar şi 9 la mandibulă, iar la categoria de vârstă 76-85 ani, 13 la maxilar şi 8 la mandibulă. Cel mai puțin interesați par a fi incisivii ambelor arcade, cu uşoara dominanță a maxilarului (Fig. 13).

Repartiţia lotului studiat pe scoruri este prezentată în fig. 14. Stadiul superficial reprezintă aproape jumătate din totalul lotului (43\%), interesarea pulpei radiculare este prezentă la doar $12 \%$ dintre CR.

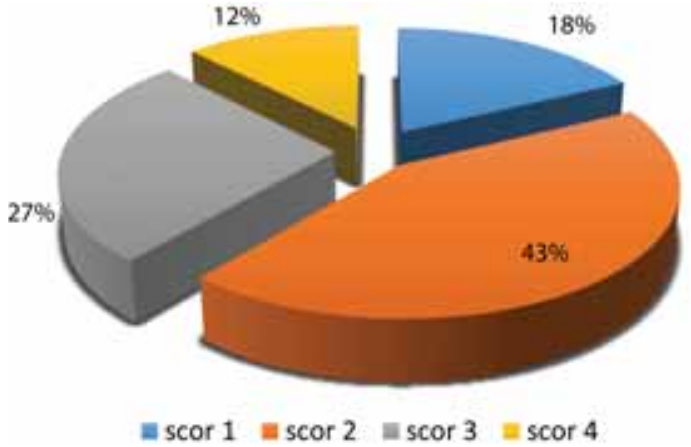

FIGURA 14. Distribuția CR pe scoruri

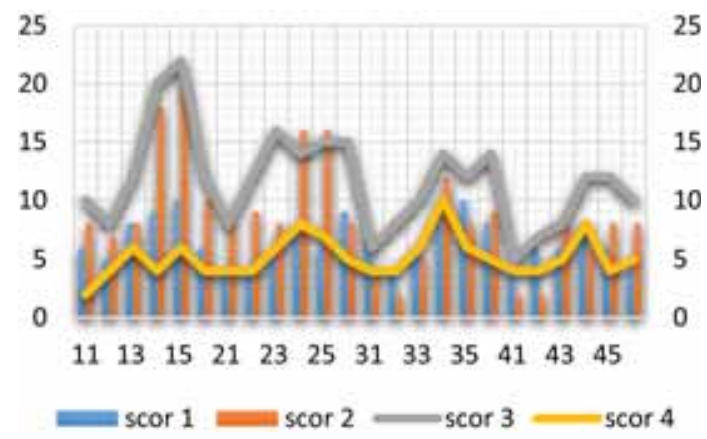

FIGURA 15. Distribuție scoruri pe categorii dinți

Repartiţia scorurilor pe categorii de dinţi arată predominanța scorurilor 2, 3 la nivelul PM maxilari (Fig. 15).

S-a determinat în ce măsură CR este asociată cu prezența unor lucrări mobile cu elemente de sprijin pe dinții afectați. 38\% dintre cazuri s-au asociat cu prezența unor restaurări mobile, astfel încât mai mult de jumătate nu prezentau astfel de lucrări (Fig. 16).

Un alt criteriu analizat a fost asocierea $\mathrm{CR}$ cu prezența plăcii bacteriene (Fig. 18). Indicele de placă bacteriană a fost calculat utilizând indicele Sil-

$\square$ वC $\square \mathrm{PM} \square \mathrm{M}$

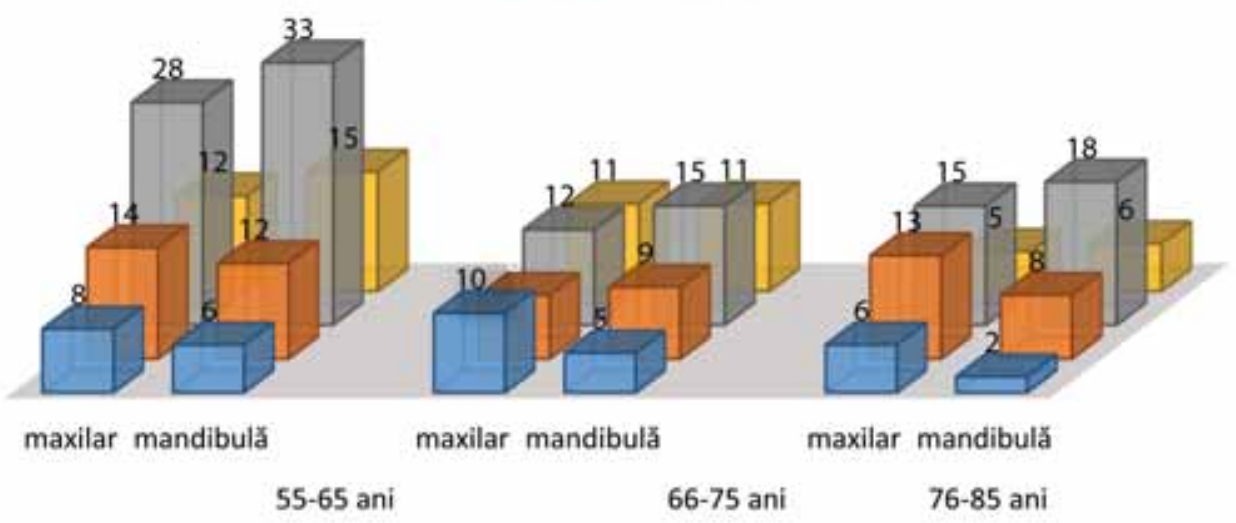

FIGURA 13. Distribuția CR pe categorii de dinți, vârstă şi maxilar 
ness şi Loe, fără colorare, ce apreciază lățimea depunerii de placă bacteriană de la nivel coronar. Valorile ce pot fi acordate sunt de la 0 la 3, pentru fiecare dinte $0=$ fără placă; $1=$ film subțire în $1 / 3$ cervicală, vizibil doar prin raclare cu sonda; $2=$ depunere moderată de placă vizibilă direct; 3 = acumulări masive ce ocupă şi spațiile interdentare.

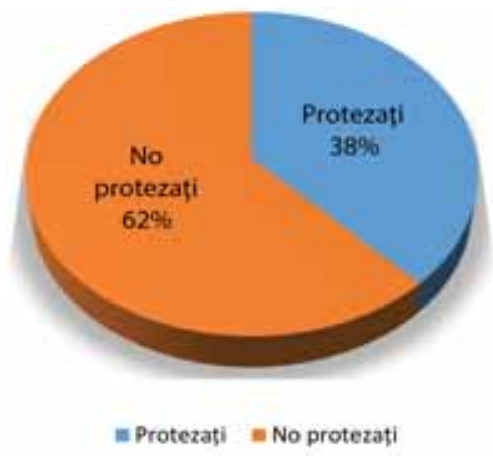

FIGURA 16. Distribuție restaurări mobile

Se constată că majoritatea pacienților prezintă o stare de igienă relativ bună materializată prin predominența scorului 2 (64\%) şi doar 9\% cu scor 3 evaluat prin prezența depozitelor masive de placă ce ocupă şi spațiul interdentar (Fig. 17).

În ceea ce priveşte alimentaţia, evaluată prin chestionarul utilizat, s-a constatat un consum de carbohidrați ridicat $(74 \%)$ vs. consum de fructe şi legume (26\%) (Fig. 18).

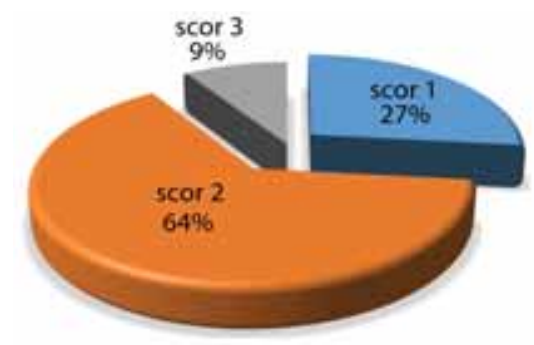

FIGURA 17. Indicele de placă bacteriană

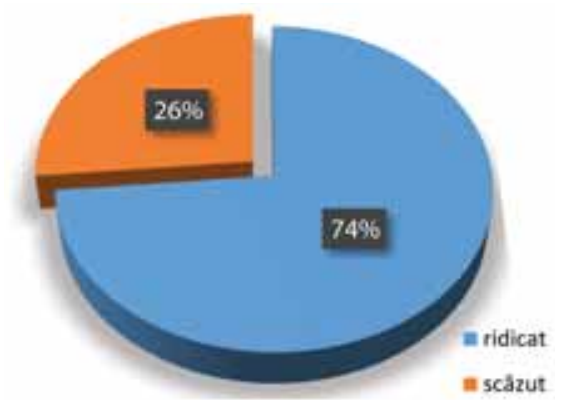

FIGURA 18. Consum carbohidrați

Legat de factorii comportamentali s-a constatat că 50\% dintre pacienții lotului consumă ocazional alcool şi 36\% sunt abstinenți; puțin peste jumătate sunt nefumători şi doar 18\% sunt fumători (Fig. 19, 20).

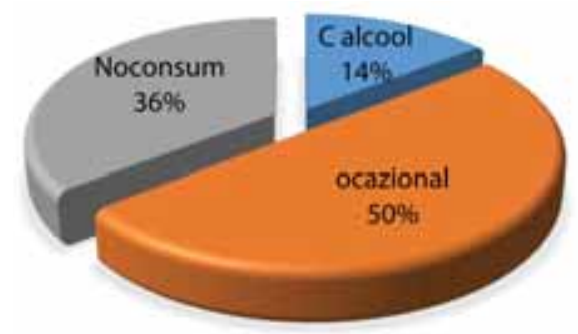

FIGURA 19. Consum alcool

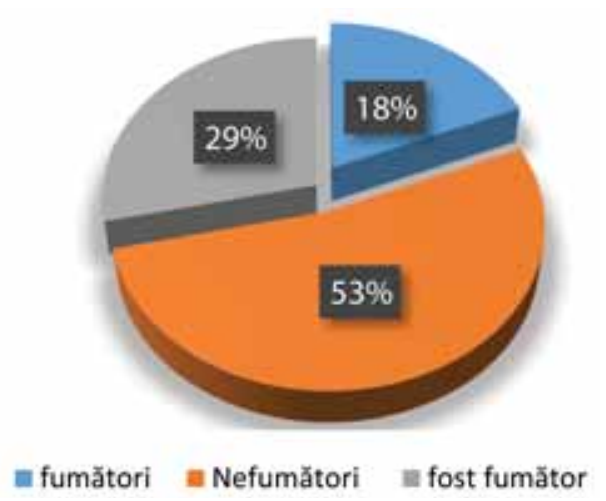

FIGURA 20. Consum tutun

Din totalul lotului de pacienți, $57 \%$ se prezintă la cabinet doar atunci când sunt obligați de simptomatologia subiectivă, iar $43 \%$ dintre pacienți sunt monitorizați prin programări periodice pentru consultații şi tratament (Fig. 21).

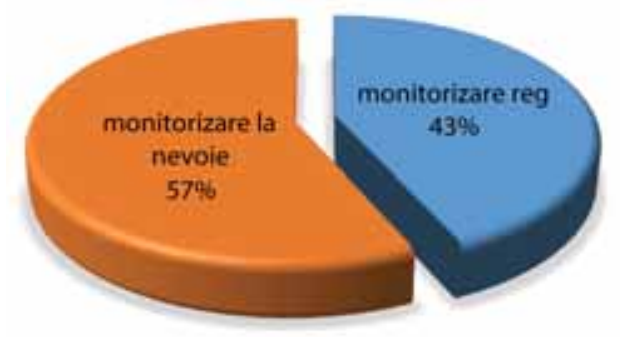

FIGURA 21. Ritmul consultațiilor

S-a determinat indicele de carie radiculară (ICR) pentru lotul examinat. Indicele cariilor rădăcinilor (ICR) este o metodă de raportare a CR care măsoară gravitatea bolii şi schițează gradul de risc al populației. Prin definiție, ICR se bazează pe supoziţia că recesiunea gingivală este o condiție necesară pentru dezvoltarea CR şi că ea trebuie să fie evidentă la momentul examinării. Situații care pot subestima ICR sunt prezența recesiunii doar a epi- 
teliului gingival sau prezența unei pungi parodontale false.

ICR s-a calculat prin examinarea fiecărui dinte maxilar şi mandibular şi completarea datelor obținute într-o diagramă (12). Coloanele reprezintă cele 4 suprafețe radiculare (V, O, M, D) ale fiecărui dinte, iar rândurile înregistrează una dintre următoarele posibile situații clinice: absența recesiunii gingivale sau prezența recesiunii asociată cu dinte indemn, carie sau restaurare.

$$
I C R=\frac{R^{*}+R^{*}}{R D+R F+R^{*}} \times 100
$$

$$
\begin{aligned}
& * \mathrm{RD}=\text { recesiune }+ \text { carie } \\
& * \mathrm{RF}=\text { recesiune }+ \text { restaurare } \\
& * \mathrm{RN}=\text { recesiune fără carie }
\end{aligned}
$$

Prin înlocuirea cu datele obținute pentru lotul studiat, a rezultat un ICR de $44,82 \%$.

Numărul şi procentul pentru fiecare categorie analizată sunt prezentate în Tabelul 1.

\begin{tabular}{|c|c|c|c|}
\hline Grup & Subgrup & Nr. & Procent \\
\hline \multirow[t]{3}{*}{ ICR } & Recesiune şi carie & 323 & $29,4 \%$ \\
\hline & Recesiune şi restaurare & 179 & $16,10 \%$ \\
\hline & Recesiune gingivală & 618 & $54,40 \%$ \\
\hline \multirow[t]{3}{*}{ ASA } & ASA1 & 55 & $30,60 \%$ \\
\hline & ASA2 & 110 & $61,10 \%$ \\
\hline & ASA3 & 15 & $8,30 \%$ \\
\hline \multirow{3}{*}{ Consum_alcool } & Fără alcool & 64 & $35,60 \%$ \\
\hline & Ocazional & 90 & $50,00 \%$ \\
\hline & Zilnic & 26 & $14,40 \%$ \\
\hline \multirow[t]{2}{*}{ Consum_hidrocarburi } & Ridicat & 106 & $58,90 \%$ \\
\hline & Scăzut & 74 & $41,10 \%$ \\
\hline \multirow[t]{2}{*}{ Educație } & Studii medii & 97 & $53,90 \%$ \\
\hline & Studii superioare & 83 & $46,10 \%$ \\
\hline \multirow[t]{3}{*}{ Factori_comp } & Nefumător & 48 & $26,70 \%$ \\
\hline & Fost Fumător & 80 & $44,40 \%$ \\
\hline & Fumător & 52 & $28,90 \%$ \\
\hline \multirow[t]{2}{*}{ Gen } & Bărbați & 92 & $51,10 \%$ \\
\hline & Femei & 88 & $48,90 \%$ \\
\hline \multirow[t]{3}{*}{ Igienă_orală } & Scor 1 & 52 & $28,90 \%$ \\
\hline & Scor 2 & 101 & $56,10 \%$ \\
\hline & Scor 3 & 27 & $15,00 \%$ \\
\hline \multirow[t]{2}{*}{ Monitorizare_PAC } & Ocazional & 102 & $56,70 \%$ \\
\hline & Regulat & 78 & $43,30 \%$ \\
\hline \multirow[t]{2}{*}{ Prezența_protezelor_mobile } & $\mathrm{Nu}$ & 112 & $62,20 \%$ \\
\hline & da & 68 & $37,80 \%$ \\
\hline \multirow[t]{2}{*}{ Retracție_gingivală } & nu & 112 & $62,20 \%$ \\
\hline & da & 68 & $37,80 \%$ \\
\hline \multirow[t]{4}{*}{ Scor_CR } & Scor 1 & 32 & $17,80 \%$ \\
\hline & Scor 2 & 78 & $43,30 \%$ \\
\hline & Scor 3 & 48 & $26,70 \%$ \\
\hline & Scor 4 & 22 & $12,20 \%$ \\
\hline \multirow[t]{3}{*}{ Vârstă } & 55-65 ani & 46 & $25,60 \%$ \\
\hline & 66-75 ani & 71 & $39,40 \%$ \\
\hline & 76-85 ani & 63 & $35,00 \%$ \\
\hline \multirow[t]{3}{*}{ Venit } & Mediu & 75 & $41,70 \%$ \\
\hline & Ridicat & 63 & $35,00 \%$ \\
\hline & Scăzut & 42 & $23,30 \%$ \\
\hline Total & & 180 & \\
\hline
\end{tabular}

Datele au fost analizate în SPSS versiunea $21 \mathrm{cu}$ $\mathrm{CI}=95 \%$ şi $\mathrm{p} \leq 0,05$.

TABELUL 1. Descrierea datelor obținute în studiu 
TABELUL 2. Media, mediana şi SD

\begin{tabular}{|c|c|c|c|c|c|c|c|c|c|c|c|c|}
\hline & Proteze & ASA & Venit & Educ. & $\begin{array}{c}\text { Carbo- } \\
\text { hidrați }\end{array}$ & $\begin{array}{c}\text { Igienă } \\
\text { orală }\end{array}$ & Scor & $\begin{array}{c}\text { Fact. } \\
\text { comp. }\end{array}$ & Alcool & Vârstă & Retracție & $\begin{array}{c}\text { Monito- } \\
\text { rizare }\end{array}$ \\
\hline Media & 1,83 & 2,11 & 1,51 & 1,38 & 1,82 & 0,35 & 2,27 & 1,09 & 0,73 & 1,48 & 0,42 & 2,15 \\
\hline Mediana & 2 & 2 & 2 & 1 & 2 & 0 & 2 & 1 & 1 & 1 & 0 & 2 \\
\hline $\begin{array}{c}\text { Deviația } \\
\text { standard }\end{array}$ & 0,586 & 0,805 & 0,503 & 0,488 & 0,628 & 0,479 & 0,927 & 0,751 & 0,631 & 0,502 & 0,497 & 0,74 \\
\hline Media & 1,73 & 2,13 & 1,41 & 1,44 & 1,91 & 0,41 & 2,4 & 0,95 & 0,85 & 1,39 & 0,33 & 2,03 \\
\hline Mediana & 2 & 2 & 1 & 1 & 2 & 0 & 2 & 1 & 1 & 1 & 0 & 2 \\
\hline $\begin{array}{c}\text { Deviația } \\
\text { standard }\end{array}$ & 0,582 & 0,708 & 0,494 & 0,5 & 0,672 & 0,494 & 0,891 & 0,741 & 0,72 & 0,49 & 0,473 & 0,809 \\
\hline Media & 1,78 & 2,12 & 1,46 & 1,41 & 1,86 & 0,38 & 2,33 & 1,02 & 0,79 & 1,43 & 0,38 & 2,09 \\
\hline Mediana & 2 & 2 & 1 & 1 & 2 & 0 & 2 & 1 & 1 & 1 & 0 & 2 \\
\hline $\begin{array}{c}\text { Deviația } \\
\text { standard }\end{array}$ & 0,584 & 0,757 & 0,5 & 0,493 & 0,65 & 0,486 & 0,909 & 0,747 & 0,677 & 0,497 & 0,436 & 0,775 \\
\hline
\end{tabular}

TABELUL 3. Alte date statistice (f, sig., mean difference)

\begin{tabular}{|l|c|c|c|}
\hline & f & sig. & mean difference \\
\hline Prezență proteze & 2,694 & 0,102 & $-0,061$ \\
\hline ASA & 0,86 & 0,355 & 0,099 \\
\hline Venit & 3,579 & 0,06 & $-0,016$ \\
\hline Educație & 2,976 & 0,086 & 0,102 \\
\hline Consum_hidrocarburi & 2,58 & 0,11 & $-0,063$ \\
\hline Igienă_orală & 0 & 0,995 & $-0,094$ \\
\hline Scor_CR & 0,073 & 0,788 & $-0,126$ \\
\hline Factori_comp & 0,205 & 0,651 & 0,132 \\
\hline Consum_alcool & 0,589 & 0,444 & $-0,124$ \\
\hline Vârstă & 4,421 & 0,037 & 0,092 \\
\hline Retracție gingivală & 6,235 & 0,013 & 0,094 \\
\hline Monitorizare pac & 0,587 & 0,445 & 0,118 \\
\hline
\end{tabular}

\section{DISCUTुII}

Studiul prezent a analizat prevalența CR şi corelația dintre ICR şi câteva categorii de factori etiologici.

CR este o afecțiune care afectează un număr tot mai mare de pacienți adulți. În studiul de față, prevalența a fost de $36 \%$. Datele din literatură legate de acest aspect sunt heterogene.

Intervalul raportat pentru incidența CR este larg, de la 10,1 la 40,6\% (13). Unii autori raportează valori mari ale prevalenței, astfel, Beck şi colab.. citați de Chi D.L., au raportat un procent de $63 \%$ CR la un lot de 520 de adulți cu vârsta de peste 65 ani, dintre care $25 \%$ erau netratate (13). Într-un alt studiu realizat pe pacienți din aceeaşi categorie de vârstă, s-a găsit că 76\% dintre ei au avut CR (14). În contrast, Chi D.L. şi colab. au raportat o prevalență a CR de 19,6\% (15). iar alți autori au arătat procente mai puțin ridicate cuprinse între 20 şi $42 \%$ $(16,17)$.

Conform datelor Centrului Naţional de Sănătate şi Nutriție în SUA, între 1999 şi 2004, prevalenţa
CR a fost de 30,8\% în rândul adulților cu vârste cuprinse între 50 şi 64 de ani, comparativ cu 10,4\% în rândul adulților cu vârsta din intervalul 20-34 ani. CR au afectat aproximativ un sfert din adulții australieni şi mai mult de jumătate dintre vârstnici (18).

În ceea ce priveşte vârsta, studiile trebuie extinse la categorii de vârstă suficient de mari pentru a le permite să fie un predictor semnificativ al incidenței CR.

În studiul de faţă, lotul a avut vârsta între 55 şi 85ani şi s-a constatat că prezenţa CR creşte proporțional cu vârsta $(p=0,037)$. Există o unanimitate în studiile publicate legată de corelaţia între apariţia CR şi pacienții vârstnici $(19,20,21,22)$.

Şi repartiţia pe categorii de sexe a CR este controversată, în ciuda unor studii care arată că bărbații sunt expuşi unui risc mai mare la CR decât femeile. Un studiu din 2015 arată un procent de 40,8\% bărbați față de 59,2\% femei care prezintă CR (23).

Explicații posibile pentru aceste neconcordanțe pot fi determinate de particularitățile afecțiunilor dentare legate de gen, care pot fi similare sau diferite pentru bărbați şi femei.

În studiul prezent, bărbaţii au reprezentat puţin peste jumătate din lot, dar repartiția pe sexe a demonstrat o diferență nesemnificativă dintre femei şi bărbaţi.

În acest studiu, ICR, care exprimă riscul de apariție a $\mathrm{CR}$ din cauza expunerii suprafeței radiculare la mediul bucal, a fost de $44,82 \%$. Studiile legate de prevalența CR sunt heterogene şi cifrele nu sunt concludente. Studiile publicate au raportat game largi pentru prevalența cariei rădăcinii (25-100\%) şi o medie a ICR între 9,7 şi 38,7. 
Astfel, studiile arată valori de 11,95\% în China (24), de $26 \%$ pentru vârstnicii britanici (25) şi $16,3 \%$ în Brazilia (26).

În contrast, adulții din Germania aveau scoruri reduse ale ICR, ce variau între 4,6\% şi 10,6\% (27).

Studiile arată că există o distribuție caracteristică a CR în funcție de categoriile de dinți.

În studiul de faţă, dinții cei mai afectați de CR sunt premolarii mandibulari la toate categoriile de vârstă, urmați de molarii mandibulari şi caninii maxilari, de asemenea, pentru toate categoriile de vârstă, iar cel mai puțin afectați au fost incisivii mandibulari.

Alte două studii, Katz şi colab. (16) şi Wallace şi colab. (28), sunt în acord cu rezultatele studiului de față. Hellyer şi colab. (29) au raportat caninii maxilari şi premolarii mandibulari ca fiind cel mai frecvent afectați de CR. Constatările noastre au confirmat faptul că premolarii şi molarii sunt cei mai sensibili. Un model similar de atac a fost observat şi în cazul suedezilor (30) şi al celor brazilieni (26). $\mathrm{Cu}$ toate acestea, este demn de remarcat faptul că aceste modele pot fi legate de frecvența ridicată a recesiunii la aceste tipuri de dinți.

În studiul prezent, susceptibilitatea de interesare a dinților a fost PM, M, C, I. Alte studii arată că apariţia CR la maxilar interesează dinții în ordinea I, C, PM, M, iar la mandibulă ordinea este M, PM, C, I (31).

Există şi suprafețe dentare care sunt mai sensibile la dezvoltarea CR. În studiul nostru, susceptibilitatea la CR a relevat că fețele vestibulare şi proximale au fost cel mai des interesate, în acord cu alte studii care au demonstrat că suprafaţa vestibulară şi proximală sunt mai sensibile decât cea palatinală sau linguală a dinţilor (28). În acest studiu, jumătate dintre CR sunt localizate pe fața vestibulară a dinților, iar suprafețele proximale sunt interesate în proporții relativ egale (27\% suprafețele meziale şi $23 \%$ suprafețele distale).

Rezultate similare raportează afectarea mai mult de jumătate a fețelor vestibulare de CR $(55,5 \%)$, urmate de suprafețele distale $(17,3 \%)$ şi meziale $(12,7 \%)(26)$.

Evoluţia procesului carios reprezintă un aspect mai puțin luat în considerație în studiile de cercetare. Astfel, există puține relatări care au luat în considerare aspectul clinic al CR. În două studii (32, 33), numărul mediu de leziuni active a fost de 2,7 şi, respectiv, 2,6 şi aproape toți indivizii au experimentat una sau mai multe suprafețe cu leziuni inactive.

Rezultatele studiul meu arată că procesele carioase cu aspect rugos şi profunzime până în $0,5 \mathrm{~mm}$, care au fost încadrate în stadiu superficial (scor 2), reprezintă aproape jumătate din totalul lotului (43\%), interesarea pulpei radiculare este prezentă la doar $12 \%$ dintre CR. Această repartiție poate să fie explicată prin prezența în lot a grupei de 55-65 ani, majoritatea studiilor din literatură având limita inferioară de vârstă 65 ani. Caria sub forma cavitară se găseşte la aprox. 1/3 din lot, în timp ce leziunile incipiente si avansate, cu interesare pulpară, au o reprezentare mai redusă.

Recesiunea gingivală poate fi considerată o condiție sine qua non pentru dezvoltarea CR. În studiul prezent, recesiunea însoțeşte $70 \%$ dintre dinţi $(\mathrm{p}=$ $0,013)$. Alte studii raportează o proporție şi mai mare a pacienților care prezintă recesiune gingivală (98,9\%) (26).

Un alt factor de risc pentru CR este reprezentat de prezența protezelor mobile, care determină depunerea plăcii bacteriene, precum şi retracţia gingivală la nivelul dinților pe care se sprijină croşetele de ancorare ale protezei. Purtarea de proteze în studiul nostru reprezintă $38 \%$. Studii anterioare au identificat însă proteza mobilă ca factor de risc pentru apariţia CR $(34,35)$.

Fumatul şi consumul de alcool sunt asociate cu producerea îmbolnăvirii parodontale şi pot fi considerate un factor de risc pentru apariția CR. În studiul de față, $1 / 3$ dintre pacienți nu consumă deloc alcool, iar puțin peste $1 / 2$ sunt nefumători, iar analiza statistică a arătat corelația dintre aceşti factori şi CR ( $p=0,034$ alcool şi $p=0,050$ fumat). Rezultatele nu sunt în acord cu alte studii care au raportat că nu există legatură între CR şi obiceiul de a fuma sau consumul de alcool (36).

Alte cercetări însă, în acord cu rezultatele acestui studiu, arată că persoanele care fumează au prezentat o prevalenţă şi o severitate semnificativ crescută a CR (18). Un alt studiu transversal pe zece ani realizat pe un lot de pacienţi cu vârste între 65 şi 85 ani a găsit o relație pozitivă între CR si fumat (37). De asemenea, alte studii au publicat relaţia dintre consumul de tutun şi CR la adulți cu vârste între 21 şi 89 ani (38) sau cu vârste între 55 şi 75 ani (39).

În lotul studiat, am găsit, de asemenea, o corelație între CR şi igiena bucală cu p =0,039 în acord 
cu un studiu longitudinal privind adulții irlandezi (vârsta medie $=69,1$ ani), care a sugerat o corelaţie între CR şi igiena bucală redusă, în timp ce nu s-a găsit o corelație cu dieta, obiceiul de fumat, consumul de alcool sau nivelul de educație (12).

O constatare importantă a fost asocierea aportului de zahăr şi RC, cu un consum de carbohidraţi ridicat $(74 \%)$ al pacienților lotului studiat. Acest lucru este, probabil, din cauza faptului că o dentină expusă prezintă o protecție redusă împotriva atacurilor cariogene, devenind vulnerabilă. Acest factor este consemnat ca a fi determinant în apariţia CR şi de către alţi autori (36).

Contrar acestor rezultate, alți autori consideră că nu există legatură între retracția gingivală şi consumul de zahăr (24).

Legat de prezentarea la cabinetul dentar, monitorizarea este asociată cu reducerea prevalenței CR.
În acest studiu, diferența dintre pacienții monitorizați şi cei care se prezintă ocazional la cabinet nu este mare, dar cu uşoară predominanţă a celor nemonitorizați.

\section{CONCLUZII}

Acest studiu a arătat faptul că incidența cariilor radiculare este influenţată semnificativ de câțiva factori de risc reprezentaţi de vârstă şi retracția gingivală.

Cunoaşterea factorilor de risc şi corelaţia lor cu ICR poate determina elaborarea unor protocoale de prevenție şi tratament individualizate, în funcție de grupa de risc a fiecărui pacient.

Notă. Autorii au contribuit în mod egal la elaborarea articolului.

Conflict of interest: none declared Financial support: none declared

\section{BIBLIOGRAFIE}

1. Kassebaum N.J., Bernabe E., Dahiya M., Bhandari B., Murray C.J., Marcenes W. Global burden of untreated caries: a systematic review and meta regression. Journal of Dental Research 2015; 94(5):650-8.

2. Clarkson J.E. Epidemiology of root caries. American Journal of Dentistry 1995; 8(6):329-34.

3. B. Gupta, C. Marya, V. Juneja, V. Dahiya. Root Caries: An Aging Problem. The Internet Journal of Dental Science. 2006 Volume 5 Number 1.

4. Imazato S., Ikebe K., Nokubi T., Ebisu S., Walls A.W.G. Prevalence of root caries in a selected population of older adults in Japan. Journal of Oral Rehabilitation. 2006; 33 (2), 137-143

5. Statistics of Finland Appendix table 1. Population by age 1900-2060 (years 2020 to 2060: projection) (Set 2016 maj). Tilgængelig fra: URL: http://www.stat.fi/til/vaenn/2015/ vaenn_2015_2015-10-30_tau_001_en.html

6. Närhi T., Syrjälä A.-M. Dental diseases and their treatment in the older population. Nor Tannlegeforen Tid. 2017; 127: 42-8

7. Kumara-Raja B., Radha G. Prevalence of root caries among elders living in residential homes of Bengaluru city, India. J Clin Exp Dent. 2016; 8(3):e260-7.

8. Ritter A.V., Shugars D.A., Bader J.D. Root caries risk indicators: a systematic review of risk models. Community Dent Oral Epidemiol. 2010 Oct; 38(5):383-97

9. Gugnani N. et al. International Caries Detection and Assessment System (ICDAS): A New Concept. Int J Clin Pediatr Dent. 2011 May-Aug; 4(2): 93-100.

10. Billings R.J. Restoration of carious lesions of the root. 1989; Gerontology 5(1):43

11. Doyle D.J., Garmon E.H. American Society of Anesthesiologists Classification (ASA Class) StatPearls Publishing; 2017 Jun. https://www.ncbi.nlm.nih.gov/books/ NBK441940/
12. Hayes M. et al. Risk indicators associated with root caries in independently living older adults. Journal of Dentistry. 2016; 51:8-14

13. Chi D.L., Shyue C. Preventing and Managing Root Caries. Decisions in Dentistry. March 1, 2016 http:// decisionsindentistry.com/article/preventing-and-managingroot-caries/

14. Ahluwalia K.P., Cheng B., Josephs P.K., Lalla E., Lamster I.B. Oral disease experience of older adults seeking oral health services. Gerodontology. 2010; 27:96-103.

15. Chi D.L., Berg J.H., Kim A.S., Scott J. Northwest Practicebased Research Collaborative in Evidence-based DENTistry. Correlates of root caries experience in middle-aged and older adults in the Northwest Practice-based Research Collaborative in Evidence-based DENTistry research network. J Am Dent Assoc. 2013; 144:507-516.

16. Katz R.V., Hazen S.P., Chilton N.M., Mumma R.D. Prevalence and intraoral distribution of root caries in an adult population. Caries Res 1982; 16:265-271.

17. Katz R.V. Root caries. Is it the caries problem of the future? J Can Dent Assoc 1985; 51:511-515.

18. Hariyani N., Spencer A.J., Luzzi L., Do L.G. Root caries experience among Australian adults. Gerodontology. 2017 Sep; 34(3):365-376.

19. Gati Dand Vieira A.R. Elderly at Greater Risk for Root Caries: A Look at theMultifactorial Risks with Emphasis on Genetics Susceptibility. International Journal of Dentistry Volume 2011, Article ID 647168.

20. Marino R.J., Fu C.S., Giacaman R.A. Prevalence of root caries among ambulant older adults living in central Chile. Gerodontology. 2015: 32: 107-14.

21. Hayesa M. Risk indicators associated with root caries in independently living older adults. Journal of Dentistry. 51 (2016) 8-14 
22. Bansal V. et al. Roots caries a problem of growing age. JIADS, 2011; 2 (2):43-45

23. Cristina Saura-Moreno C. et al. Root caries analysis in working population of 35-44 years of age (Spain). Med Oral Patol Oral Cir Bucal. 2017 Sep 1; 22 (5):e527-35.

24. Du M.Q., Jiang H., Tai B.J., Wu B., Bian Z. (2009). Root Caries Patterns and Risk Factors of Middle-aged and Elderly People in P.R. China. Community Dentistry and Oral Epidemiology, 37(3), 260-266.

25. Steele J.G., Sheiham A., Marcenes W., Fay N., Walls A.W.G. Clinical and behavioral risk indicators for root caries in older people. Gerodontology 2001; 18:95-101.

26. Watanabe M.G.C. Root caries prevalence in a group of Brazilian adult dental patients. Braz Dent J 2003; 14:153-6.

27. Splieth C.H., Schwahn C.H., Bernhardt O., John U. Prevalence and distribution of root caries in Pomerania, North-East Germany. Caries Res 2004; 38: 333-40

28. Wallace M.C., Retief D.H., Bradley E.L. Prevalence of root caries in a population of older adults. Gerodontics 1988; 4:84-9.

29. Hellyer P.H., Beighton D., Heath M.R., Lynch E.J.R. Root caries in older people attending a general practice in East Sussex. Br Dent J 1990; 169:201-6.

30. Fure S., Zickert I. Prevalence of root surface caries in 55, 65 and 75-year-old Swedish individuals. Community Dent Oral Epidemiol 1990; 18:100-5.

31. Root caries: classification, causes, clinical features and treatment. Juniordentist.com. 2014, http://www. juniordentist.com/category/operative-dentistry
32. Fejerskov O., Luan W.M., Nyvad B., BudtzJørgensen E., Holm-Pedersen P. Active and inactive root surface caries lesions in a selected group of 60- to 80-year-old Danes. Caries Research. 1991; 25, 385-391.

33. Ekstrand K.R., Poulsen J.E., Hede B., Twetman S., Qvist V., Ellwood R.P. A randomized clinical trial of the anti-caries efficacy of 5,000 compared to 1,450 ppm fluoridated toothpaste on root caries lesions in elderly disabled nursing home residents. Caries Research. 2013; 47, 391-398.

34. Lawrence H.P., Hunt R.J., Beck J.D. Three-year root caries incidence and risk modeling in older adults in North Carolina, J. Public Health Dent. 55 (1995) 69-78.

35. Locker D. Incidence of root caries in an older Canadian population, Commun. Dent. Oral Epidemiol. 24 (1996) 403-407.

36. Rabia A. Factors Associated with Exposure and Caries of Root Surface among Sample of Pakistani Patients Visiting a University Hospital. Jul-Sep 2016; JPDA; 25(03):81-6.

37. Fure $S$. Ten-year cross-sectional and incidence study of coronal and root caries and some related factors in elderly Swedish individuals. Gerdontology. 2004; 21:130-40.

38. Christensen L.B., Bardow A., Ekstrand K., Fiehn N.E., Heitmann B.L., Qvist V. et al. Root caries, root surface restorations and lifestyle factors in adult Danes. Acta Odontol Scand. 2015;73:467-73.

39. Bharateesh J.V., Kokila G. Association of root caries with oral habits in older individuals attending a rural health centre of a dental hospital in India. J Clin Diagn Res. 2014; 8:ZC80-ZC82. 